\title{
Everything the oculoplastic surgeon needs to know about permanent makeup. Case series and literature review
}

\section{Todo lo que el cirujano oculoplástico necesita saber del maquillaje permanente. Serie de casos y revisión de la literatura}

\author{
Adriana Dávila-Camargo*, Osiris Olvera-Morales, and José L. Tovilla-Canales
}

Instituto de Oftalmología Fundación Conde de Valenciana, Mexico City, Mexico

\begin{abstract}
Introduction: Dermopigmentation consists of the implantation of pigment particles in the epidermis and the superficial dermis with a dermograph. It is used as a permanent cosmetic alternative or as a complementary treatment to aesthetic or reconstructive surgeries. It can be done on lips, eyebrows, or eyelids to correct minor scars or balance facial features. Objective: To describe the disorders treated with dermopigmentation, the demographic characteristics of the treated population, and complications. Method: A descriptive, prospective, and observational study was conducted in the department of oculoplastics of the Instituto de Oftalmología Conde de Valenciana, from 2016 to 2019. The variables studied were age, gender, the reason for dermopigmentation, coadjuvant procedures, satisfaction, and complications. Results: The procedure was performed in 20 patients, 34 eyebrows, and 16 eyelids. All the patients were female. The average age was 54.25 years (range: 21-82). The main reason for dermopigmentation was aesthetic (55\%), eyebrow alopecia (35\%) and scars (10\%). Coadjuvant procedures such as blepharoplasty or botulinum toxin were used in $35 \%$ of patients. All patients were satisfied with the outcome. No complications were reported. Conclusions: Dermopigmentation of the periocular area is a useful tool in the arsenal of the oculoplastic surgeon to enhance the periocular aesthetics of the patients and improve surgical results. It is a technically simple procedure and in our study, it is reported without complications.
\end{abstract}

Key words: Dermopigmentation. Micropigmentation. Eyebrow tattoo. Eyelid tattoo. Permanent makeup.

\section{Resumen}

Introducción: La micropigmentación consiste en la implantación de partículas de pigmento en la epidermis y la dermis superficial con un dermógrafo. Se utiliza como una alternativa cosmética estable o como tratamiento complementario a cirugías estéticas o reconstructivas. Se puede realizar en labios, cejas o párpados para corregir cicatrices menores o equilibrar rasgos faciales. Objetivo: Describir las patologías tratadas con micropigmentación, las características demográficas de la población tratada y las complicaciones presentadas, y revisar la literatura existente. Método: Se realizó un estudio descriptivo, prospectivo y observacional en el departamento de oculoplástica del Instituto de Oftalmología Conde de Valenciana, de 2016 a 2019. Las variables estudiadas fueron edad, sexo, motivo de la micropigmentación, procedimientos coadyuvantes, satisfacción del paciente y complicaciones. Resultados: Se realizó el procedimiento en 20 pacientes, 34 cejas y

Correspondence:

*Adriana Dávila-Camargo

Paseo del tecnológico 909 int 520

Col. Residencial Tecnológico Torreón, Coahuila Date of reception: 27-05-2020

27272, Mexico

E-mail: adrydav@gmail.com

2604-1731/๑ 2020 Sociedad Mexicana de Oftalmología. Published by Permanyer. This is an open access article under the CC BY-NC-ND license (http://creativecommons.org/licenses/by-nc-nd/4.0/).
Date of acceptance: 03-11-2020

DOI: 10.24875/RMOE.M21000171
Available online: 19-03-2021 Rev Mex Oftalmol (Eng). 2021;95(4):129-136

www.rmo.com.mx 
Rev Mex Oftalmol (Eng). 2021;95(4)

16 párpados. El 100\% de las pacientes eran de sexo femenino. La edad promedio fue de 54.25 años (rango: 21-82). La principal razón por la que se realizó la micropigmentación fue por estética (55\%), alopecia de cejas (35\%) y cicatrices (10\%). En el $35 \%$ de los casos se realizaron procedimientos coadyuvantes, como blefaroplastias o toxina botulínica. Todas las pacientes estuvieron satisfechas con el resultado. No se reportaron complicaciones. Conclusiones: La micropigmentación del área periocular es una herramienta útil en el arsenal del cirujano oculoplástico para realzar la estética periocular y enaltecer los resultados quirúrgicos de los pacientes. Es un procedimiento técnicamente sencillo y en nuestro estudio se reportó sin complicaciones.

Palabras clave: Micropigmentación. Dermopigmentación. Tatuaje de ceja. Tatuaje de párpado. Maquillaje permanente.

\section{Introduction}

Micropigmentation consists in the implantation of pigment particles in the epidermis and superficial dermis using fine needles connected to a device called a dermograph, to produce a change in color ${ }^{1}$. It started as a medical procedure in the hands of Van der Velden in 1984 , although today it is considered more as a form of tattooing than as a surgical procedure ${ }^{2}$. It is also known as dermo pigmentation, permanent makeup, or permanent eyeliner. It is a stable cosmetic alternative, unlike conventional cosmetic products that offer a temporary effect ${ }^{3}$. Despite its name, it is not permanent, since the pigments lighten over time due to the degradation of pigment particles by macrophages, but the pigment granules endocytosed by fibroblasts remain in the connective tissue of the eyelid, which represents a non-inflammatory reaction by non-toxic foreign substances ${ }^{4}$. A current trend from which it must be differentiated is the so-called microblading, which uses another type of device more similar to a scalpel, called tabori, and the pigments are implanted in a more superficial plane in the basal layer of the epidermis, without reaching the dermis ${ }^{5}$. The duration of this procedure is 1 to 2 years, while micropigmentation lasts for 3 to 4 years. Other areas of medicine also use micropigmentation, like reconstructive breast surgery to reconstruct the areola, in dermatology to give a uniform color in diseases such as vitiligo or scars, or for hair restoration in alopecia, and there is even a reported case of nail bed restoration due to bilateral loss $s^{1,6-10}$. For the oculoplastic surgeon, it can be considered as a complementary treatment to cosmetic or reconstructive surgeries, and can be performed on the lips, eyebrows, and eyelids to modify or correct minor scars and balance facial features.

The periocular area is extremely important for human facial expression. The eyebrows are one of the most important and visible characteristics of the face, considered the superior aesthetic frame of the eyes and capable of changing expressiveness ${ }^{11}$. Raising the eyebrows denotes surprise, medial angle depression expresses irritability, and lateral depression evokes sadness. It is not surprising that women from time immemorial try to change their eyebrows for better aesthetics $^{12}$. From a cosmetic point of view, neat and defined eyebrows make a face look much more attractive and stylized, and the lining of the eyelids provides a natural frame, rejuvenates and enhances the look by giving the impression of enlarging the eyes. It can be performed on the upper or lower lid margins (Fig. 1). Permanent makeup is a viable option in patients who do not want or cannot wear makeup on a daily basis for several reasons, such as allergies to cosmetics, osteoarthritis, visual loss or lack of time, as well as scars or senile or pharmacological alopecia ${ }^{13}$.

Currently, there is a boom in this procedure performed by non-medical personnel. Despite being a common procedure that is considered safe, it is still invasive and with potential complications, reported from $2 \%$ to $20 \%{ }^{1,2}$. However, in a medical setting, they are extremely rare, because it is practiced in a sterile environment.

As the periocular area is within the scope of ophthalmology and oculoplastic surgeons, we undertook the task of carrying out the following scientific research to determine the demographic characteristics of the patients, the disorders that can be managed with this procedure and potential complications. In addition to a case series, we present a literature review we performed on this subject.

\section{Methods}

A descriptive, prospective, and observational study was carried out in the oculoplastics department of the Instituto de Oftalmología Conde de Valenciana, from 2016 to 2019. The study was submitted to the research, bioethics, and biosafety committee, and was approved in accordance with its statutes. Hospital patients were notified of the availability of the micropigmentation service and all those who requested the 


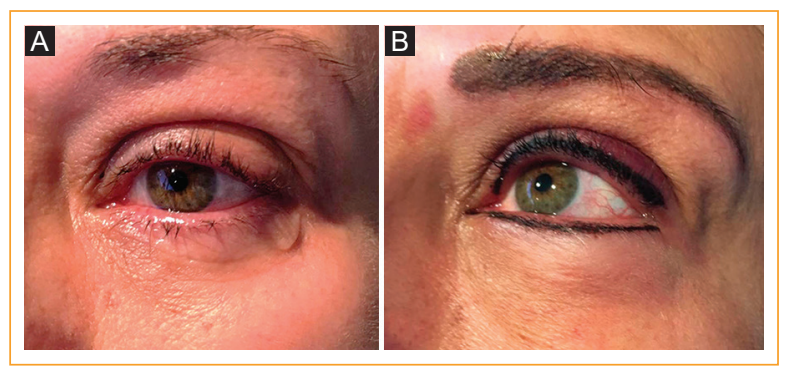

Figure 1. Micropigmentation of the upper and lower lid margin (A: before; B: after).

service during that period were enrolled. Patient follow-up was from 1 month to 24 months. The inclusion criteria were being of legal age and signed informed consent. The variables that were studied were age (years), sex (male or female), the reason for requesting micropigmentation, the use of adjunctive procedures such as botulinum toxin or blepharoplasty, satisfaction with the result (yes/no) and the presence of complications. The sample size was for convenience according to the patients who requested the service during the study period. Descriptive statistics of demographic data were performed with Microsoft Excel for Mac, version 15.13.3.

Prior to the procedure, the patient received an informed consent and a questionnaire about relevant medical history ${ }^{14}$. Photographs were taken before the procedure in all cases. The material used for each patient and for each micropigmentation session was new and sterile. We used a dermograph (Biotouch, Mosaic) with 1, 3, 5, or 6-gauge pigment needles, according to the shade of the patient (Form Line, Cosmética Permanente SA de CV, Mexico), eyebrow templates, subcutaneous anesthesia (2\% lidocaine, PiSA, Guadalajara, Mexico), syringe for anesthesia, gauze, cotton, and alcohol for asepsis (Fig. 2). For the eyebrows, the area was measured placing the line with the eyebrow template according to the patient's face or her preference. Beauty is a constantly evolving concept, and the ideal eyebrow shape has been described according to age, sex, and race, and is divided into three anatomic parts: head, body, and tail; however, it is actually customized according to the patient's features or the style that she wishes to follow ${ }^{11,12,15-17}$. The pigment is chosen according to the patient's skin and hair color, to make it harmonious with the face ${ }^{13}$. In the eyelids, the thickness and the extension of the line are established, either upper or lower. After injecting a local anesthetic in the area to be pigmented, with the dermograph and deep

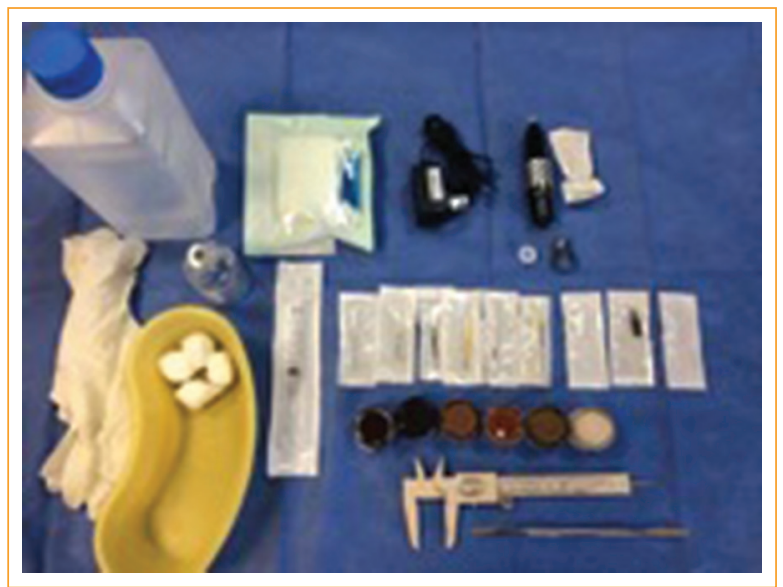

Figure 2. Material used for micropigmentation.

penetration needles, the pigment is placed in the indicated area, always keeping the skin under tension (Video attached). In the end, an antibiotic ointment is placed, and the patient is instructed to use cold compresses and avoid exposure to the sun for at least 10 days. The patient is always informed that the initial pigment is much darker than the final result once it heals. After 10-15 days we propose a post-procedure correction in those patients who wish to modify the thickness or length of the dermo pigmentation line, once the inflammation in the area has decreased and there are no scabs.

For the literature review in PubMed and Google Scholar, the following keywords were used for articles in English: "Dermo pigmentation", "permanent makeup", "cosmetic tattoo" and "micropigmentation". We included in the review all the articles relevant to our study (discarding those that had more emphasis on breast reconstruction or alopecia areata), which are cited. All articles were independently reviewed by an investigator (ADC). All abstracts and keywords were reviewed. In no case, there were more than 60 entries found.

\section{Results}

During the study period, 20 patients requested the service and were included in the study. The procedure was performed on 34 eyebrows and 16 eyelids. All patients were women. The average age was 54.25 years (range: 21-82). The main reason for requesting micropigmentation was aesthetics in 11 patients $(55 \%)$, eyebrow alopecia in $7(35 \%)$, and trauma scars in the periocular area in $2(10 \%)$ (Table 1). In 13 patients, no adjuvant procedures were performed 
Table 1. Demographic characteristics and procedures performed in patients undergoing periocular micropigmentation.

\begin{tabular}{|c|c|c|c|c|c|}
\hline Patient & $\begin{array}{c}\text { Age } \\
\text { (years) }\end{array}$ & Reason & Eyebrows & Eyelids & $\begin{array}{l}\text { Other } \\
\text { procedure }\end{array}$ \\
\hline 1 & 45 & Aesthetic & 0 & 2 & UB \\
\hline 2 & 42 & Aesthetic & 2 & 0 & No \\
\hline 3 & 48 & Aesthetic & 2 & 0 & No \\
\hline 4 & 60 & Aesthetic & 0 & 4 & BT \\
\hline 5 & 31 & Aesthetic & 2 & 0 & No \\
\hline 6 & 64 & Alopecia & 2 & 0 & No \\
\hline 7 & 65 & Aesthetic & 4 & 0 & No \\
\hline 8 & 61 & Aesthetic & 0 & 2 & No \\
\hline 9 & 68 & Alopecia & 2 & 0 & No \\
\hline 10 & 55 & Alopecia & 2 & 0 & No \\
\hline 11 & 70 & Alopecia & 2 & 0 & LB \\
\hline 12 & 68 & Alopecia & 2 & 0 & $\begin{array}{l}\text { LB and } \\
\text { UB }\end{array}$ \\
\hline 13 & 75 & Alopecia & 2 & 0 & UB \\
\hline 14 & 64 & Alopecia & 2 & 0 & UB \\
\hline 15 & 40 & Aesthetic & 2 & 4 & No \\
\hline 16 & 44 & Aesthetic & 0 & 2 & No \\
\hline 17 & 41 & Aesthetic & 2 & 0 & No \\
\hline 18 & 41 & Injury & 2 & 0 & DIC \\
\hline 19 & 21 & Injury & 2 & 2 & No \\
\hline 20 & 82 & Aesthetic & 2 & 0 & No \\
\hline
\end{tabular}

LB: lower blepharoplasty; UB: upper blepharoplasty; BT: botox; DIC: dacryointubation.

(65\%), in 3 patients a blepharoplasty was performed prior to micropigmentation (15\%) and in another 4 patients, we performed, respectively, application of botulinum toxin and hyaluronic acid $(5 \%)$, lower blepharoplasty $(5 \%)$, upper and lower blepharoplasty $(5 \%)$ and dacryointubation plus eyelid reconstruction (5\%) (Fig. 3). There were no complications. Patients reported $100 \%$ satisfaction at one week and one month after the procedure. Two years after the procedure, 4 patients $(25 \%)$ requested retouching due to pigment tone attenuation.

Regarding the literature review, for "dermo pigmentation" there were 16 results, for "micropigmentation" 47 results, for "cosmetic tattoo" 694 results and for "permanent makeup" 121 results, in July 2020.

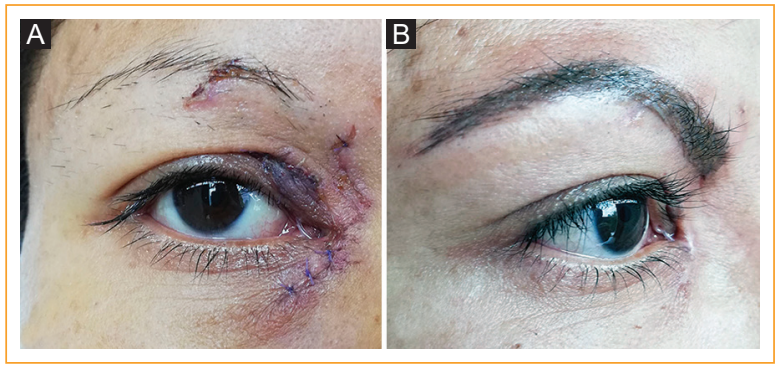

Figure 3. Patient with eyebrow micropigmentation after a dog bite that required eyelid reconstruction plus closed dacryointubation (A: before; B: after).

\section{Discussion}

The interest in carrying out this research is based on a large number of patients in our service with asymmetries or periocular scars who seek a solution to their problem and cannot find it in a safe medical and scientific environment. It must be remembered that the primary objective of medical tattoos is to restore part of the physical integrity of the patient. In addition, the procedure seeks to assist in the psychological recovery of physical or mental trauma as a consequence of illness, surgery, or an accident. There is a lot of literature on this matter in the field of cosmetology, but there are few medical studies about this useful tool. Currently, it is a procedure that is carried out in areas such as spas and aesthetics. However, it is important to consider it beyond a merely cosmetic procedure, as an adjunct to cosmetic or reconstructive surgeries, but which can be carried out by certified doctors since it is not exempt from some complications and there are even clinics for tattoo complications ${ }^{18,19}$. Tattoos have occasionally been linked to the development of malignancies such as malignant melanoma, basal cell carcinoma, and squamous cell carcinoma. The tattoo is suspected to delay diagnosis due to the masking effect of the pigment. Other complications are abnormal scarring or keloid scars, as well as allergic reactions, as informed in the report issued by the Food and Drug Administration in $2004^{4,20}$.

It is fair to clarify that if our tattoo results do not live up to expectations, it is not because the technique used is deficient, but because in reconstructive cases, sometimes the application conditions are far from ideal and because we have a lot to learn from tattoo artists as we try to optimize outcomes for our patients. However, we do consider that it is a procedure that can be left in 
the hands of medical personnel, since we can improve the conditions of application and sterility, such as the application of anesthesia, and it would be unfortunate if patients were deprived of our professional commitment. In countries like France and Italy, the nipple-areola tattoo is a reimbursed procedure $e^{1,19}$.

Commenting a bit about the history of tattoos, it was in the islands of the South Pacific where the use of pigments apparently began ${ }^{1}$. The word "tattoo" comes from a Tahitian term (Ta tatau), which means appropriate and balanced, and describes the implantation of pigment under the $\mathrm{skin}^{21}$. In the $5^{\text {th }}$ century, tattoos were used as punishment for criminals. In the $18^{\text {th }}$ century, tattoos reappeared on the old continent when sailors began to return from distant lands with tattoos done by the native people they encountered on those journeys. It was not until relatively recently, with all the exposure to tattoos, the greater social acceptance and the availability of removing unwanted tattoos, that the practice was no longer seen as something clandestine, and it is estimated that to date tattoos have a prevalence of up to $10 \%$ in the general population ${ }^{1,21,22}$. Regarding the medical application, there are references to their use from $5300 \mathrm{BC}$ on the body of a Neolithic hunter. In 1911, Kolle used pigments to tattoo lips. In 1920, Bettman tattooed a patient's eyebrows and eyelids after cilia disappeared as a consequence of maxillofacial surgery. In 1974 the first tattoo of the mammary areolas was made. It was in 1984 that Van der Velden adapted Japanese tattoo techniques to apply them in different medical disciplines ${ }^{23}$.

In our case, as oculoplastic surgeons, with an interest in the periocular area, our focus is the eyebrows and eyelids. The eyebrows are one of the most important and visible characteristics of the face, as they are capable of changing expressiveness. It is an excellent option to modify or correct minor scars or lack of hair from cancer treatments, alopecia areata, trichotillomania, genetics, or advanced age, and thus balance facial features ${ }^{24,25}$. The ideal brow shape has been described, divided into three anatomic parts: head, body, and tail ${ }^{11}$. The height of the eyebrow has also changed over time: in the 1970s the height was above the orbital rim and today feminine beauty standards have been displacing it inferiorly, even masculinizing it. It has been commented that it may be, in part, due to the paradigm shift regarding equality between men and women that a masculinized eyebrow is more acceptable and requested ${ }^{12}$.

Micropigmentation is increasingly requested by patients who have undergone cosmetic eyelid surgeries

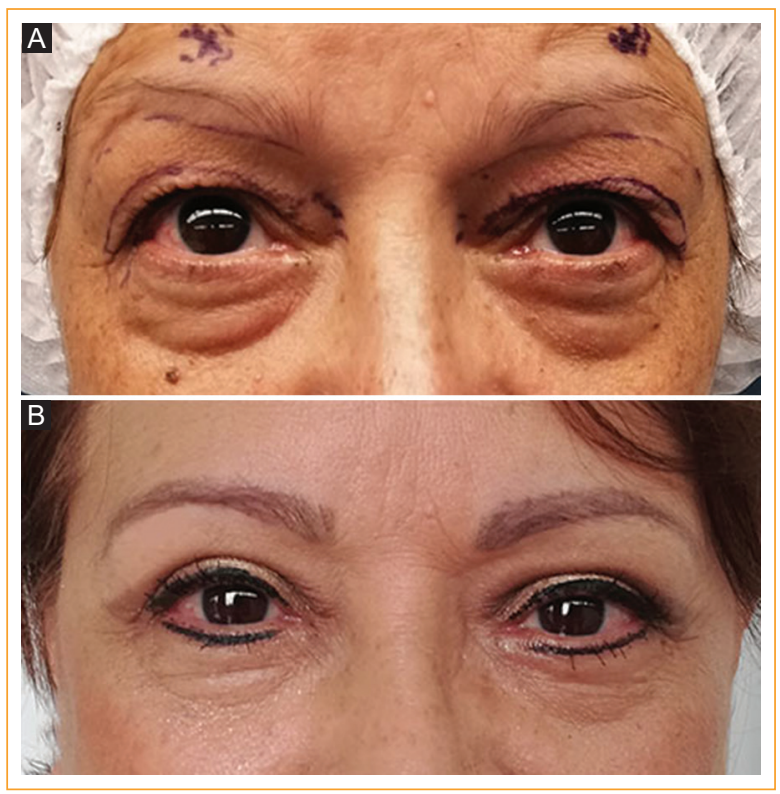

Figure 4. Patient with eyebrow micropigmentation after upper blepharoplasty (A: before; B: after).

and are looking for definitive cosmetic treatments that provide greater facial harmony. In our study, we observed that the most frequent reason for performing micropigmentation was for aesthetics. Regarding disorders, the most frequent was eyebrow alopecia. Five patients $(25 \%)$ underwent a previous eyelid surgical procedure like upper blepharoplasty, lower blepharoplasty, and repair of eyelid trauma with involvement of the lacrimal duct. In this last patient, it is worth mentioning that the change in her mood after treatment was extremely noticeable. Other studies have corroborated the "enormous confidence gain regarding physical appearance" and the advantage in terms of saving money on makeup and time $^{2}$. This emphasizes micropigmentation as a complementary treatment to enhance the aesthetic results of surgical procedures (Fig. 4). Some advantages reported in the literature that were also mentioned by our patients are that it is waterproof, timesaving, uncomplicated, without allergy to make-up and fashionable. Some may also request it due to physical difficulties, such as visual loss or osteoarthritis of the hands ${ }^{2,13,26}$. However, whatever the reason, patients need to be aware of the risks inherent in the procedure and make an informed decision. The biggest risk is that the procedure is performed by someone inexperienced. The most frequent complications related to the technique described in the literature are «needle trauma» with skin lesions, 
"overworked tattoo» or "pigment overdose», as well as infection by contaminated pigments ${ }^{18}$.

We were also able to observe that it is a procedure that achieved a $100 \%$ satisfaction with all patients, and also, they felt confident that a physician was the one performing the procedure. Although we had no complications in our study, in our deliberate PubMed search we found some that are worth commenting on. For example, adverse reactions have been mentioned in patients with tattoos that require magnetic resonance imaging due to the metal derivatives that could be found in commercial pigments, since they are still foreign particles in the body, especially red and black pigments that contain iron oxide that can heat up during magnetic resonance imaging and cause burns (although it is concluded that a tattoo should not be a limitation to use this study method due to the low incidence of cases) $)^{27,28}$.

While pigments can be organic or metallic, tattoo inks often contain metal contaminants. Pigments are generally inert and well-tolerated: however, the formation of granulomas, allergic and lichenoid reactions have been reported, although rare, especially with red pigments because they have mercury components ${ }^{22,26}$. Pigment legal issues are discussed later. Adverse reactions to tattoos have been described mostly as part of an allergic, lichenoid, pseudolymphomatous or granulomatous spectrum ${ }^{21}$. The immune mechanisms involved are still the subject of speculation, and reactions can occur months to years later. The development of sarcoidosis secondary to cosmetic tattoos has also been described in several cases, using triamcinolone injections as treatment ${ }^{29-31}$.

Henna tattoos are rarely used for the periocular area, but we think it is important to mention them. The pigment obtained from the henna bush (Lawsonia inermis) may cause an allergic reaction, although it is common that $p$-phenylenediamine (PPD) is added to obtain a black pigment, which is inexpensive, but unfortunately is a strong sensitizer. PPD is used since henna has a range of colors that goes from red to brown but is never black $^{21}$. PPD is not authorized for use on skin, eyelashes, or eyebrows because it causes severe allergic reactions such as contact dermatitis. Exposing children to PPD can make them extremely sensitive to this compound, which would exclude them from future occupations such as a printer, stylist and everything related to textiles, because they could have a systemic reaction with generalized lymphadenopathy and fever ${ }^{32}$.

One disadvantage that oculoplastic surgeons observe in terms of tattooing the eyelids or eyebrows in older patients is when performing procedures such as blepharoplasty or browpexy. If the tattoo is asymmetrical, it can make it difficult to obtain the expected result for the patient or cause asymmetries in the tattoo that affect the final result, for example, many times, the pigmented line of the upper eyelid. As a separate comment, we would add that we must be extremely careful when marking our patients for blepharoplasty if they have a tattoo, especially regarding symmetry, because although there are laser devices to remove tattoos, there are no studies about tattoo removal of the eyelids.

The location of the pigment very close to the eyelid and ocular border makes it difficult to remove this pigment with laser. When we use lasers on the skin, they emit high-energy light pulses at a specific wavelength that are absorbed by the water and chromophores present in the skin. The laser light is transformed into thermal energy, which then acts on small sections of the skin, layer by layer ${ }^{33}$. Depending on the depth of the layer in which the laser acts, it is considered ablative or non-ablative. Examples of ablative lasers are pulsed carbon dioxide and erbium: $Y A G$, and an example of a non-ablative laser is the Q-switched neodymium: YAG. Q-switched (QS) is an option that restricts the duration of the pulse and thus the pigment particles reach high temperatures very quickly without damaging the adjacent healthy skin, and leave a much smaller scar (a process called "selective photothermolysis") ${ }^{34,35}$. Several options have been studied for years with acceptable results, for example the neodymium: YAG laser, but it is not possible to remove the pigment $100 \%$ and it is more effective in black pigments, and depending on the compounds of the pigment, because they react differently to the light waves emitted by the laser ${ }^{36-39}$. Patients must always be reminded that with a single session it is seldom possible to remove the entire tattoo. Six to ten sessions are necessary and topical anesthesia is required ${ }^{34}$. Another more current and more effective option for different skin types is the PicoWay system, which works in the picosecond range ${ }^{40}$. While the nanosecond pulse durations in QS lasers are measured in billionths of a second, the picosecond technology of the PicoWay laser system uses pulses that are measured in trillionths of a second, making it more efficient at breaking down melanin in benign pigmented lesions and particles of tattoo ink, so the body can easily dispose of debris as part of its natural biological removal processes ${ }^{41}$. This type of picosecond laser would be ideal for the eyelid border, as long as corneal protectors are used. Using 
lasers of another range, such as pulsed light or carbon dioxide, can result in significant scarring and no removal of the tattoo.

An extremely important part to mention, especially because we are certified specialists, is the current legislation in Mexico regarding this type of procedure. In accordance with the Regulation of Sanitary Control of Products and Services, in its twenty-fifth title bis, in article 224 bis 1 to 16 , mentions that a health control card is required with a validity of 2 years, at a cost of 5573 Mexican pesos, and notice of operation of the premises where the procedure is carried out; the process is free of charge ${ }^{14}$. Not having a health card can lead to fines of up to 12,000 days of minimum wage ${ }^{42}$. Before the procedure, the patient should be interrogated and receive an explanation about the risks, a reminder that the procedure is irreversible, and the aftercare. Minors under 18 must have a letter of acceptance signed by their parents or guardians. The decree mentions that the material must be disposable and sterile, and as for pigments, they must be innocuous and insoluble.

The risk of infection associated with tattooing depends largely on the hygiene regimens and the experience of the tattoo artist. It is up to the specialist to minimize the risk of infection with the established hygiene protocols, and to the patient or client to make a weighted decision in this regard. Many times, it is not easy for the potential client to verify if guidelines are followed, but in addition to the individual risk profile, the post-treatment care by the patient also determines the rate of complications. As already mentioned, in many cases of infection poor hygiene standards are the cause, but sometimes the pigments can be contaminated. A study of commercially available pigments revealed contamination with anaerobic bacteria in three of eight pigments, which could theoretically cause an infection $^{43}$. It should also be noted that tattoo artists are aware of the complications that pigments can have depending on the color they are made of, since each color may have a different reaction ${ }^{44}$. Some cases of complications from tattoos of particular interest to ophthalmologists are the report of Candida endophthalmitis secondary to a tattoo in an asplenic patient, emphasizing the importance of asking about medical history; conjunctival injury secondary to penetration of the needle into the full thickness of the eyelid; and a case of retinal vasculitis and cystic macular edema with permanent visual loss secondary to a tattoo, probably associated with a hypersensitivity reaction produced by the subcutaneous injection of antigens, similar to the ocular inflammation mechanism associated, for example, with melanin-induced sympathetic ophthalmia or uveitis ${ }^{4,45,46}$. Another relevant topic for ophthalmologists is the reactivation of the herpes simplex and herpes zoster viruses due to tattoos ${ }^{21}$.

To avoid possible complications, like penetrating the eyeball, the most important thing to do is be aware that complications can occur and know how to solve them. To anesthetize the eye, it is recommended to always do it laterally and with the needle parallel to the eye. Corneal protectors can be used after topical anesthesia and asking the patient to look down 4 .

Based on what was observed in this study, we consider that, in addition to the non-surgical procedures to which the oculoplastic surgeon is used to (botulinum toxin, facial peels, facial fillers), dermo pigmentation should be considered part of the tools that can be used. We must always remember to complete a detailed questionnaire on the medical history of our patients, first for legal reasons and second for the prevention of complications, for example, previous surgeries, use of medications or lasers. In the field of oculoplastics, and especially with patients seeking cosmetic results, always have a realistic conversation about the expectations of the treatment to avoid problems in the future. Remember the phrase of the masters: "Everything that is discussed before surgery is an explanation, and after surgery is an excuse", which applies to any procedure. Five more minutes with the patient can prevent hours of discussion and a bad outcome.

\section{Conclusions}

Periocular dermo pigmentation is an excellent tool to enhance the periocular aesthetics of the patient in the field of oculoplastics. Despite being a procedure classified as "non-medical" by the general population, it must be remembered that it is actually a minor surgery. There are several safety and health concerns to consider, as well as a basic understanding of the procedure. It is a simple technique that rarely has complications and could be part of the oculoplastic surgeon's arsenal in our mission to enhance the anatomy, self-esteem, and surgical results of patients. An oculoplastic surgeon can not only help patients see better, but also make them look better and, above all, feel better, since self-esteem is an important factor in the mental health of our patients. The key to success is education, preparation, and realistic expectations. 
Rev Mex Oftalmol (Eng). 2021;95(4)

\section{Funding}

The authors received no funding for this work.

\section{Conflicts of interest}

The authors declare no conflicts of interest.

\section{Ethical disclosures}

Protection of human and animal subjects. The authors declare that the procedures followed were in accordance with the regulations of the relevant clinical research ethics committee and with those of the Code of Ethics of the World Medical Association (Declaration of Helsinki).

Confidentiality of data. The author states that he has followed the guidelines of his institution on the publication of patient data.

Right to privacy and informed consent. The author has obtained the informed consent of the patients and/ or subjects referred to in the article. The corresponding author is in possession of this document.

\section{References}

1. Boulart L, Mimoun M, Noel W, Malca N, Chaouat M, Boccara D. Dealing with tattoos in plastic surgery. Complications and medical use. Ann Chir Plast Esthet. 2017:62:E23-9.

2. Armstrong ML, Saunders JC, Roberts AE. Older women and cosmetic tattooing experiences. J Women Aging. 2009;21:186-97.

3. Gallaga J, Herrera A, Flores M. Maquillaje permanente, micropigmentación. Revista Cofepris. 2016;1:26.

4. De M, Marshak H, Uzcategui N, Chang E. Full-thickness eyelid penetration during cosmetic blepharopigmentation causing eye injury. J Cosmet Dermatol. 2008;7:35-8.

5. Martin C. ¿Cuál es la diferencia entre microblading y micropigmentación de cejas y cuál elegir? Rincón de Belleza. Disponible en: https://Www. Rincondebelleza.Com/Diferencia-Entre-Microblading-Micropigmentacion-De-Cejas-Cual-Elegir/.

6. Vassileva S, Hristakieva E. Medical applications of tattooing. Clin Dermatol. 2007;25:367-74.

7. Halder R, Young C. New and emerging therapies for vitiligo. Dermatol Clin. 2000;18:79-89.

8. Rassman W, Pak J, Kim J. Combining follicular unit extraction and scalp micropigmentation for the cosmetic treatment of alopecias. Plasr Reconstr Surg Glob Open. 2017;5: E1420.

9. Saed S, Om I, Bergfeld W. Hair camouflage: a comprehensive review. Int J Womens Dermatol. 2017;16(3, 1 Suppl):S75-S80.

10. Renzoni A, Pirrera A, Lepri A, Cammarata P, Molinaro R, Dalla Vedova A. Medical tattooing, the new frontiers: a case of nail bed treatment. Ann Ist Super Sanit. 2017;53:334-6.

11. Gupta J, Kumar A, Chouhan K, Ariganesh C, Nandal V. The science and art of eyebrow transplantation by follicular unit extraction. J Cutan Aesthet Surg. 2017;10:66-71.

12. Griffin GR, Kim JC. Ideal female brow aesthethics. Clin Plastic Surg. 2013;40:145-55

13. Wetzel CL. Permanent cosmetics. Plastic Surg Nurs. 2012;32:117-9.

14. Diario Oficial de la Federación. Decreto por el que se reforma y adicionan diversas disposiciones del Reglamento de Control Sanitario de Productos y Servicios. 24 de abril de 2012. Disponible en: http://www.dof.gob.mx/ nota_detalle.php?codigo $=5244887 \&$ fecha $=24 / 04 / 2012$

15. Roth JM, Metzinger SE. Quantifying the arch position of the female eyebrow. Arch Facial Plast Sur. 2003;5:235

16. Schreiber J, Singh N, Klatsky S. Beauty lies in the "eyebrow" of the beholder: a public survey of eyebrow aesthetics. Aesthet Surg J. 2005;25:348-52.
17. Sclafani AP, Jung M. Desired position, shape, and dynamic range of the normal adult eyebrow. Arch Facial Plast Surg. 2010;12:123-7.

18. Hutton K, Sepehri M, Serup J. Tattooist-associated tattoo complications: "overworked tattoo," "pigment overload" and infections producing early and late adverse events. Dermatology. 2020;236:208-15.

19. Starnoni M, Pinelli M, Franceschini G, De Santis G. A rare case of nipple-areolar complex partial necrosis following micropigmentation: what to learn? Plast Reconstr Surg Glob Open. 2019;7:E2494.

20. Food And Drug Administration. FDA alerts consumers about adverse events associated with "permanent makeup". FDA Talk Paper, July 2 , 2004. Disponible en: http://www.fda.gov/bbs/topics/answers/2004/ ans01295.html,2004

21. Kaatz M, Elsner P, Bauer A. Body-modifying concepts and dermatologic problems: tattooing and piercing. Clin Dermatol. 2008;26:35-44.

22. Jacob Cl. Tattoo-associated dermatoses: a case report and review of the literature. Dermatol Surg. 2008;28:962-5.

23. Van Der Velden EM, Drost BH, ljsselmuiden OE, Baruchin AM. Dermatography as a treatment after periocular surgery. Orbit. 2004;23:175-81.

24. Radmanesh M, Shafiei S, Naderi AH. Isolated eyebrow and eyelash trichotillomania mimicking alopecia areata. Int J Dermatol. 2006;45:557-60.

25. Modjtahedi BS, Kishan AU, Schwab IR, Jackson WB, Maibach HI. Eyelash alopecia areata: case series and literature review. Can J Ophthalmol. 2012;47:333-8.

26. De Cuyper C. Permanent makeup: indications and complications. Clin Dermatol. 2008;26:30-4.

27. Alsing KK, Johannesen $\mathrm{HH}$, Hansen $\mathrm{RH}$, Serup J. Tattoo complications and magnetic resonance imaging: a comprehensive review of the literature. Acta Radiol. 2020;61:1695-700.

28. Klitscher D, Blum J, Kreitner KF, Rommens PM. [MRT induced burns in tattooed patients. Case report of a traumatic surgery patient.] Unfallchirurg. 2005;108:410-4.

29. Baumgartner M, Feldmann R, Breier F, Steiner A. Sarcoidal granulomas in a cosmetic tattoo in association with pulmonary sarcoidosis. J Dtsch Dermatol Ges. 2010;8:900-2.

30. O'Beirne SL, O'dwyer DN, Walsh SM, Dodd JD, Crotty TB, Donnelly SC. The lady with the dragon tattoo. Ir J Med Sci. 2006;186:157-60.

31. Tittelbach J, Peckruhn M, Schliemann S, Elsner P. Sarcoidal foreign body reaction as a severe side-effect to permanent makeup: successful treatment with intralesional triamcinolone. Acta Derm Venereol. 2018;98:458-9.

32. Corrente S, Moschese V, Chianca M, Graziani S, Iannini R, La Rocca M, et al. Temporary henna tattoo is unsafe in atopic children. Acta Pediatr. 2007:96:461-71

33. Devgan L, Singh P, Durairaj K. Minimally invasive facial cosmetic procedures. Otolaryngol Clin N Am. 2019;52:443-59.

34. Bernstein E. Laser tattoo removal. En: Markus RF, editor. Lasers in plastic surgery. New York: Thieme Medical; 2007. p. 175-92.

35. Serup J, Bäumler W, editors. Diagnosis and therapy of tattoo complications. With atlas of illustrative cases. Basel: Karger. Curr Probl Dermatol. 2017; 52:113-23

36. Watts MT, Downes RN, Collin JRO, Walker NPJ. The use of Q-switched $\mathrm{Nd}$ :YAG laser for removal of permanent eyeliner tattoo. Opthalmic Plast Reconstr Surg. 1992;8:292-4.

37. Setlur J. Cosmetic and reconstructive medical tattooing. Curr Opin Otolaryngol Head Neck Surg. 2007;15:253-7.

38. Goldman A, Wollina U. Severe unexpected adverse effects after permanent eye makeup and their management by Q-switched Nd:YAG laser. Clin Interv Aging. 2014;9:1305-9.

39. Barbosa de Oliveira CG, Cohen S, Alves V. Laser assisted tattoo removal: a literature Review. Surg Cosmet Dermatol. 2013;5:289-96.

40. Ross V, Naseef G, Lin C, Kelly M, Michaud N, Flotte T, et al. Comparison of responses of tattoos to picosecond and nanosecond Q-switched neodymium:YAG lasers. Arch Dermatol. 1998;134:167-71

41. Kwan W, Li M, Lourdhurajan R, Wang CC. Treatment guidelines for the PicoWay® laser system in skin of color. Picosecond laser therapy for benign pigmented lesions. Supplement to Practical dermatology; 2019. Disponible en: https://practicaldermatology.com/articles/2019-mar-insert/ treatment-guidelines-for-the-picoway-laser-system-in-skin-of-color

42. Secretaría de Salud refuerza el control sanitario de tatuajes y perforaciones en la piel. Comunicado de prensa No. 343. Ciudad de México, 25 de septiembre de 2012. Disponible en: http://www.salud.gob.mx/ssa_ app/noticias/datos/2012-09-25 5939.html.

43. Charnock $\mathrm{C}$. [Tattooing dyes and pigments contaminated with bacteria]. Tidsskr Nor Laegeforen. 2004;124:933-5.

44. Maarouf M, Saberian C, Segal R, Shi V. A new era for tattoos, with new potential complications. J Clin Aesthet Dermatol. 2019;12:37-8.

45. Alexandridou A. Candida endophthalmitis after tattooing in an asplenic patient. Arch Ophthalmol. 2002;120:518

46. Moschos MM, Guex-Crosier Y. Retinal vasculitis and cystoid macular edema after body tattooing: a case report. Klin Monbl Augenheilkd. 2004;221:424-6. 